\title{
The influence of elastin degradation products, glucose and atorvastatin on metalloproteinase-1, $-2,-9$ and tissue inhibitor of metalloproteinases-1, $-2,-3$ expression in human retinal pigment epithelial cells
}

\author{
Mariola Dorecka², Tomasz Francuz'1, Wojciech Garczorz¹, Krzysztof Siemianowicz ${ }^{\circledR}$ \\ and Wanda Romaniuk² \\ 1Department of Biochemistry, School of Medicine in Katowice, Medical University of Silesia, Katowice, Poland; 2 Department of Ophthalmology, \\ School of Medicine in Katowice, Medical University of Silesia, Katowice, Poland
}

Purpose: Hyperglycemia and increased concentrations of elastin degradation products (EDPs) are common findings in patients with diabetes, atherosclerosis and hypertension. The aim of this study was to assess the influence of high glucose, EDPs and atorvastatin on MMP-1, MMP-2, MMP-9 and TIMP1-3 gene expression in human retinal pigment epithelial cells (HRPE) in vitro. Method: HRPE were cultured for 24 hours with the substances being tested (glucose, EDPs), alone or in combination. Additionally, the cells were treated with atorvastatin in two different concentrations ( 1 or $10 \mu \mathrm{M})$. After incubation, total cellular RNA was extracted and used for gene expression evaluation. Gene expression was measured using the real-time RT-PCR technique. Results: Glucose, EDPs and atorvastatin had no impact on TIMP-1 and TIMP-3 expression. HRPE cells treated with glucose or EDPs with the addition of atorvastatin had a statistically significant decrease of TIMP-2 expression; glucose alone decreased MMP-1 expression. Atorvastatin decreased expression of all assessed genes, except TIMP-1 and TIMP-3 in a dose-dependent manner. Conclusions: Our results confirm the importance of MMPs and TIMPs in retinal vascular biology. Atorvastatin-induced MMPs gene expression can deeply affect extracellular matrix turnover, which may play an important role in the progression of ocular diseases.

Key words: metalloproteinase, TIMP, atorvastatin, HRPE

Received: 14 June, 2013; revised: 26 March, 2014; accepted: 04 April, 2014; available on-line: 06 June, 2014

\section{INTRODUCTION}

Elastin is an insoluble fibrous protein and a constituent of the extracellular matrix (ECM). Partial proteolysis of elastin by activated proteinases results in the release of soluble elastin degradation products (s-EDPs) into the circulation (Sivaprasad et al., 2005). s-EDPs are produced in large quantities in several pathological processes, such as: atherosclerosis (Petersen et al., 2002), tumor progression (Lapis \& Timar, 2002; Ntayi et al., 2004), aneurysm formation and atherogenesis (Hance et al., 2002). Some authors have shown that EDPs are responsible for the up-regulation of MMPs. s-EDPs enhance angiogenesis by promoting endothelial cell migration and tubulogenesis (Brassart et al., 2001; Robinet et al., 2005). In the eye, elastin is present in Bruch's membrane and the choroidal vessels (Chong et al., 2000). Diabetic vascular complications are possibly connected with the elevated degradation of elastic fibers. As a result, s-EDPs are released into the circulating blood, increasing elastase production and elastase-like activity, free radicals generation, induction of LDL oxidation and chemotactic activity. These peptides also act with various growth factors, cytokines and vasoactive molecules released as a response to injury. They also stimulate endothelial cell cytotoxicity and can up-regulate the synthesis and activation of matrix metalloproteinases (MMPs) (Ntayi et al., 2004).

MMPs regulate important biological functions, including ECM integrity. They are expressed in normal or diseased states and participate in ECM degradation, vascular and cardiac remodeling, wound healing, tumor metastasis and neovascularization (Jones et al., 2003; Visse \& Nagase, 2003; Pepper, 2001).

MMP activity is modulated through interaction with MMP inhibitors - tissue inhibitors of metalloproteinases (TIMPs) (Brew et al., 2000; Padgett et al., 1997). Altered MMP expression and activity have been observed in several ocular diseases, such as choroid neovascularization (Lambert et al., 2002) and proliferative retinopathies (Webster et al., 1999; Sheridan et al., 2001), suggesting that these enzymes may play an important role in ocular pathology.

Situated between the neurosensory retina and the choroid, human retinal pigment epithelial (HRPE) cells form the outer blood-retina barrier. Breakdown of this barrier is observed in many ocular diseases, such as proliferative vitreoretinopathy (Troger et al.,

e-mail: ksiem@mp.pl

Abbreviations: $\mathrm{EDP}(\mathrm{s})$, elastin degradation product(s); MMP-1, matrix metalloproteinase-1; MMP-2, matrix metalloproteinase-2; MMP-9, matrix metalloproteinase-9; TIMP-1, tissue inhibitor of metalloproteinases-1; TIMP-2, tissue inhibitor of metalloproteinases-2; TIMP-3, tissue inhibitor of metalloproteinases-3; HRPE, human retinal pigment epithelium; RNA, ribonucleic acid; RT-PCR, reverse transcriptase polymerase chain reaction; ECM, extracellular matrix; LDL, low density lipoproteins; MMP(s), matrix metalloproteinase(s); TIMP(s), tissue inhibitor(s) of metalloproteinases; RPE, retinal pigment epithelium; TGF- $\beta$, transforming growth factor- $\beta$; TNF- $a$, tumor necrosis factor-a; IL-1, interleukin-1; VEGF, vascular endothelial growth factor; FBS, fetal bovine serum; ATTC, American type culture collection; DMEM/F12, Dulbecco's modified Eagle medium: nutrient mixture F-12; PBS, phosphate buffered saline; DTT, ditiotreitol; PCR, polymerase chain reaction; GADPH, glyceraldehyde 3-phosphate dehydrogenase; $A G E(s)$, advanced glycation endproduct(s); VCAM-1, vascular cell adhesion molecule-1 
Table 1. Experiment design encompassing all groups tested.

\begin{tabular}{|c|c|c|c|c|c|c|}
\hline & Control & $\begin{array}{l}\text { Glucose + } \\
\text { EDP }\end{array}$ & $\begin{array}{l}\text { Glucose + atorva- } \\
\text { statin } 1 \mu \mathrm{M}\end{array}$ & $\begin{array}{l}\text { Glucose + EDP + } \\
\text { atorvastatin } 1 \mu \mathrm{M}\end{array}$ & $\begin{array}{l}\text { Glucose + atorva- } \\
\text { statin } 10 \mu \mathrm{M}\end{array}$ & $\begin{array}{l}\text { Glucose }+\mathrm{EDP}+ \\
\text { atorvastatin } 10 \mu \mathrm{M}\end{array}$ \\
\hline Glucose & - & + & + & + & + & + \\
\hline EDP & - & + & - & + & - & + \\
\hline atorvastatin $1 \mu \mathrm{M}$ & - & - & + & + & - & - \\
\hline atorvastatin $10 \mu \mathrm{M}$ & - & - & - & - & + & + \\
\hline
\end{tabular}

2003; Cusick et al., 2003; Spraul et al., 2004; Chan et al., 2010), diabetic retinopathy (Decanini et al., 2008; Villaroel et al., 2009) and age-related macular degeneration (Johnson et al., 2003; Evans, 2001; Dunaief et al., 2002). These pathologies are characterized by increased permeability for serum components, mainly proteins and inflammatory cells. Intraocular influx of serum components is associated with leukocyte infiltration and cellular proliferation, leading to severe complications and visual deterioration (Yoshida et al., 2001).

Retinal pigment epithelial (RPE) cells are an important source of MMPs activity in the retina (Eichler et al., 2004; Ahir et al., 2002; Lee et al., 2004; Hollborn et al., 2007). The expression and activity of MMPs in RPE cells have been shown to be regulated by various cytokines and growth factors, including: transforming growth factor beta (TGF- $\beta$ ), tumor necrosis factor alfa $(\mathrm{TNF}-\alpha)$, and interleukin 1 (IL-1) (Eichler et al., 2002; Nagineni et al., 1994; Nagineni et al., 2000). MMP activity can also be controlled by growth factors, mainly the vascular endothelial growth factor (VEGF) (Hollborn et al. 2007; Hoffmann et al., 2002). Thus the RPE produces factors that support the survival of photoreceptors and ensure a structural basis for an optimal circulation and supply of nutrients (Strauss, 2005). 3-Hydroxy-3-methylglutaryl-CoA reductase inhibitors (statins) are widely used in the treatment of dyslipidemia (Ludwig \& Shen, 2006). They also reduce cardiac death and cerebrovascular events in diabetic patients (Ludwig \& Shen, 2006; Collins et al., 2004). Some studies reported beneficial effects of statins on retarding the progression of diabetic retinopathy (Sen et al., 2002; Yamagishi et al., 2006; Al-Shabrawey et al., 2008), hard exudates (Cusick et al., 2003) and macular edema (Gupta et al., 2004) in the retinas of diabetic patients.

\section{MATERIALS AND METHODS}

Cell culture. Human retinal pigment epithelial cells (HRPE) were purchased from the American Type Culture Collection (ATCC, CRL-2302). HRPE cells were grown in DMEM:F12 containing 10\% FBS and antibiot-

Table 2. Gene expression assays used in the experiment

\begin{tabular}{|c|c|c|}
\hline Gene name & Assay ID & Amplicon length \\
\hline Matrix metalloproteinase 1 (MMP-1) & Hs00899660_g1 & $134 \mathrm{bp}$ \\
\hline Matrix metalloproteinase 2 (MMP-2) & Hs01548733_m1 & $84 \mathrm{bp}$ \\
\hline Matrix metalloproteinase 9 (MMP-9) & Hs00957556_g1 & $93 \mathrm{bp}$ \\
\hline Metalloproteinase inhibitor 1 (TIMP-1) & Hs01092510_m1 & $74 \mathrm{bp}$ \\
\hline Metalloproteinase inhibitor 2 (TIMP-2) & Hs01091319_m1 & $85 \mathrm{bp}$ \\
\hline Metalloproteinase inhibitor 3 (TIMP-3) & Hs00165951_g1 & $76 \mathrm{bp}$ \\
\hline
\end{tabular}

ics as described elsewhere (Zhuge \& Xu, 2001; MarinCastano et al., 2005). HRPE were cultured for $24 \mathrm{~h}$ at $37^{\circ} \mathrm{C}$ in $5 \% \mathrm{CO}_{2}$ atmosphere in a tissue culture incubator with inducers ( $x$-elastin $0.5 \mathrm{mg} / \mathrm{L}$ (Elastin Products Company, Inc. Missouri, USA), 5 (control) or $15 \mathrm{mM}$ glucose or $x$-elastin $+15 \mathrm{mM}$ glucose) and atorvastatin at a concentration of 1 or $10 \mu \mathrm{M}$ (Table 1). After incubation, the cells were harvested and total cellular mRNA was extracted for further assays.

Isolation of total cellular RNA. Total cellular mRNA was extracted with commercially available RNA isolation kits (RNeasy Mini Kit, Qiagen) according to the manufacturer's protocol, with slight modifications. Cells were rinsed with ice-cold PBS buffer, and later lysed for 5 min on ice in RLN buffer $(50 \mathrm{mM}$ TRIS $\mathrm{HCl}, \mathrm{pH} 8.0$; $140 \mathrm{mM} \mathrm{NaCl} ; 1.5 \mathrm{mM} \mathrm{MgCl}_{2} ; 2 \mathrm{mM}$ DTT) with $0.5 \%$ (v/v) IGEPAL CA-630 (Sigma-Aldrich). After lysis, the cells were centrifuged for $5 \mathrm{~min}$ at $300 \times \mathrm{g}$, and supernatant was processed according to the kit manufacturer's protocol. The concentration of the obtained RNA and the estimated purity was determined by measuring the absorbance at 260 and $280 \mathrm{~nm}$ in a spectrophotometer (GeneQuantII, Pharmacia-Biotech). RNA samples were tested for presence of contaminating DNA and were found negative.

After isolation, RNA extracts were stored at $-70^{\circ} \mathrm{C}$ until analysis.

Real time RT-PCR. Single step RT-PCR was performed using TaqMan EZ RT-PCR reagents (Applied Biosystems). A $2 \mu$ l RNA sample was mixed with specific primer sets and PCR master mix, and was then processed in a thermocycler: $60^{\circ} \mathrm{C}$ for $30 \mathrm{~min}$; and 40 cycles: $94^{\circ} \mathrm{C}$ for 20 seconds; $65^{\circ} \mathrm{C}$ for $60 \mathrm{~s}$. Real time reaction products were detected using FAM-labeled probes (Applied Biosystems) and the LightCycler ${ }^{\circledR} 480$ instrument (Roche). For the quantitative determination of selected gene expression, ready-to-use Applied Biosystems GeneAssays were used (Table 2). Expression levels of selected genes were normalized to glyceraldehyde 3-phosphate dehydrogenase (GAPDH) internal control (GAP$\mathrm{DH}$, TaqMan ${ }^{\circledR}$ pre-developed assay reagents, Applied Biosystems No. 433764T). Genes whose expression did not change significantly were used as additional normalizers, and made possible to assess if GAPDH reference expression remained stable in the different groups tested. 


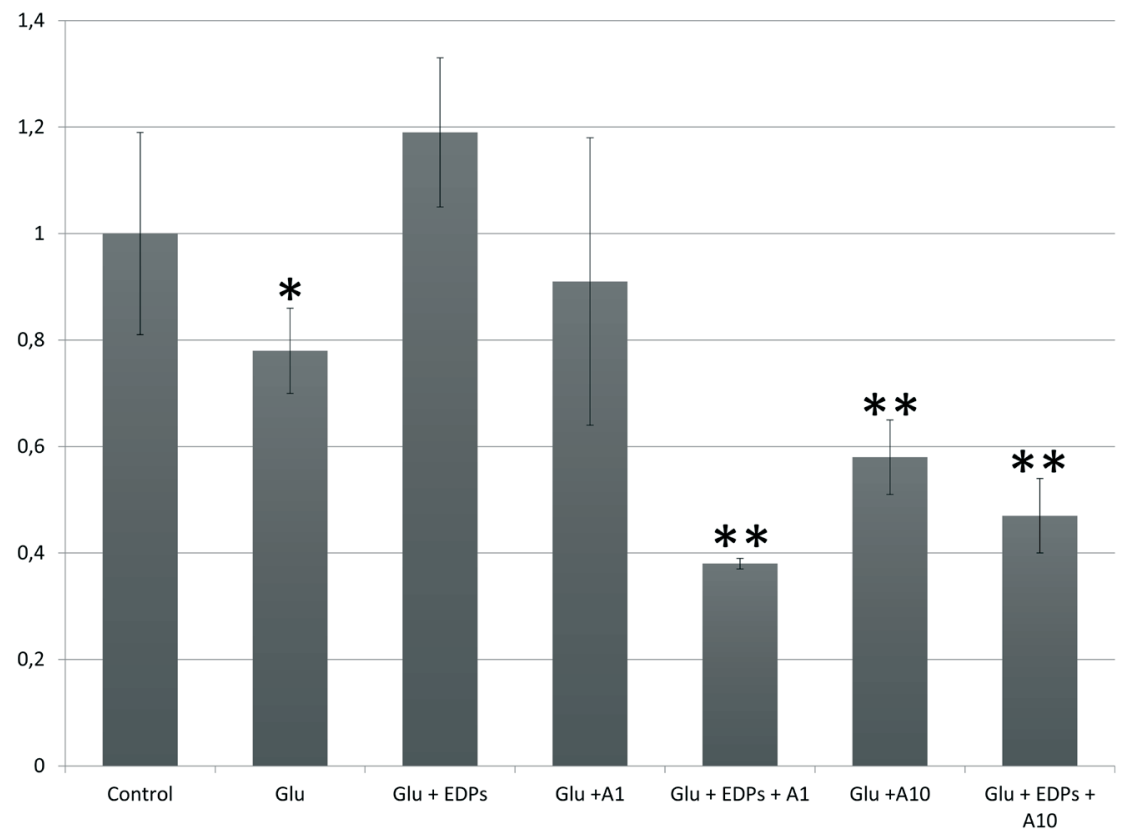

Figure 1. Expression of MMP-1gene in HRPE cells.

All results are normalized to a control group, and expressed as percentage of control. Glu, glucose 15 mM; EDPs, elastin derived peptides $(0.5 \mu \mathrm{g} / \mathrm{ml}) ; A 1$, atorvastatin $1 \mu \mathrm{M} ; \mathrm{A} 10$, atorvastatin $10 \mu \mathrm{M})$. ${ }^{*} p$-value $<0.05$. Data is presented as mean value $\pm S$.D., ${ }^{* *} p$-value $<0.01$.

\section{RESULTS}

Gene expression profiles of MMPs and TIMPs are shown on Figs. 1-4. All expression levels were normalized to a control group, so that control group expression was always set at $100 \%$.

None of the substances tested (glucose, s-EDPs and atorvastatin) had any effect on TIMP-1 and TIMP-3 expression. Neither high glucose concentration nor EDPs influenced TIMP-2 expression. However, in the HRPE cells treated with glucose or EDPs with the addition of atorvastatin, we observed a small but statistically significant decrease of TIMP-2 expression.

The influence of the tested substances on MMPs gene expression was divergent. Atorvastatin at the concentration of $10 \mu \mathrm{M}$ decreased MMP-9 expression, whereas glucose or EDPs had no effect on this gene. The relatively high standard deviation in this group rendered statistical analysis difficult due to a very low MMP-9 gene expression in HRPE. MMP-9 mRNA was observed at the method detection limit.

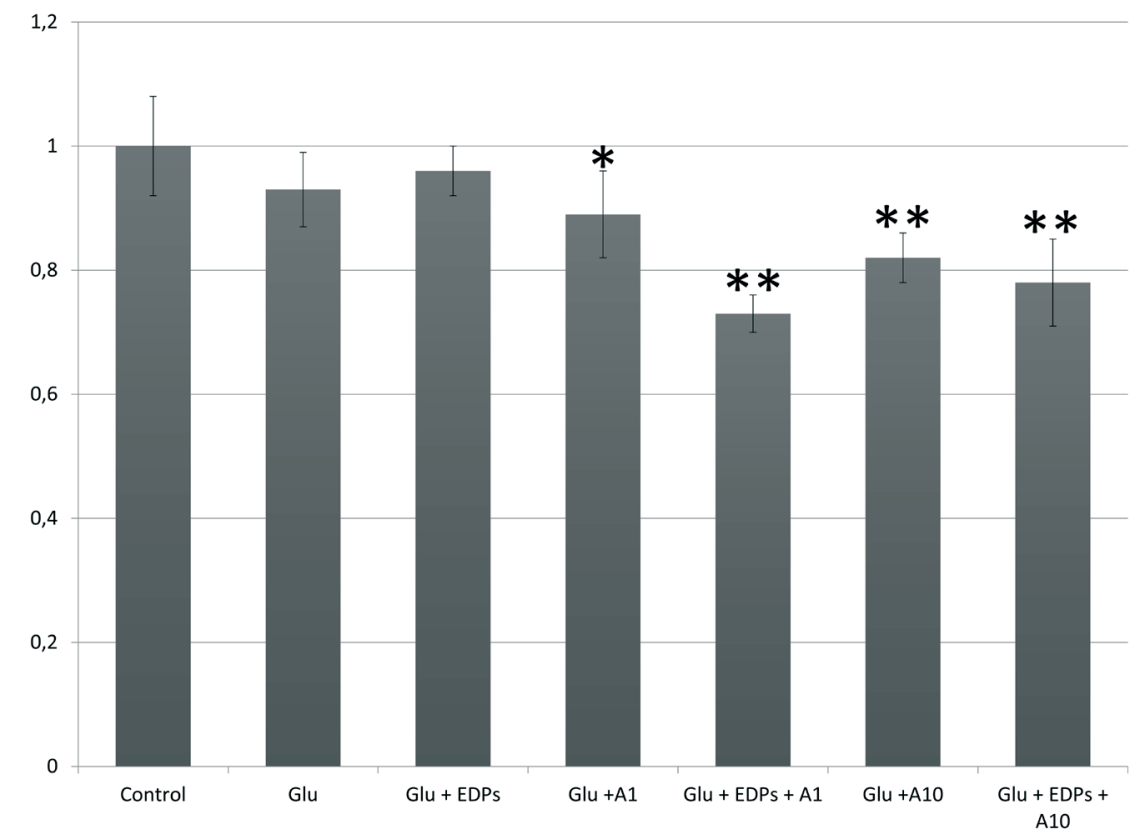

Figure 2. Expression of MMP-2 gene in HRPE cells.

All results are normalized to a control group, and expressed as percentage of control. Glu, glucose $15 \mathrm{mM}$; EDPs, elastin derived peptides $(0.5 \mu \mathrm{g} / \mathrm{ml}) ; A 1$, atorvastatin $1 \mu \mathrm{M} ; \mathrm{A} 10$, atorvastatin $10 \mu \mathrm{M})$. ${ }^{*} p$-value $<0.05$. Data is presented as mean value $\pm S$.D., ${ }^{* *} p$-value $<0.01$. 


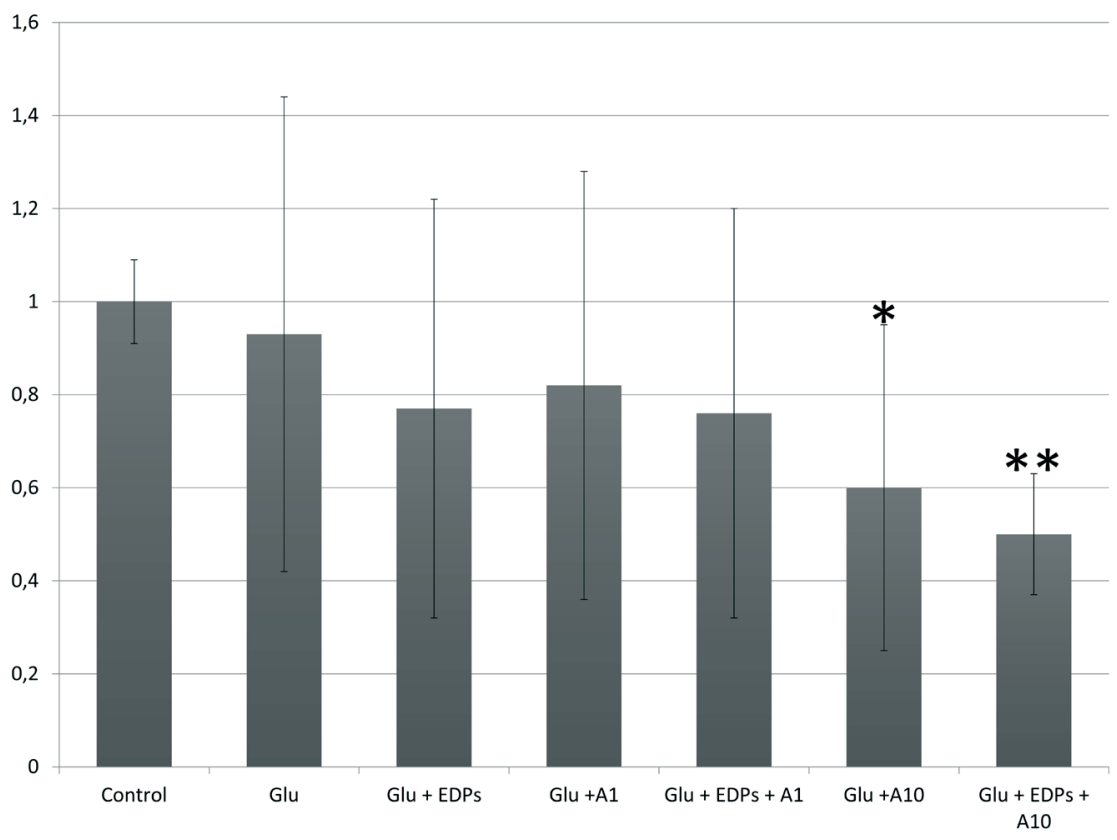

Figure 3. Expression of MMP-9 gene in HRPE cells.

All results are normalized to a control group, and expressed as percentage of control. Glu, glucose $15 \mathrm{mM}$; EDPs, elastin derived peptides $(0.5 \mu \mathrm{g} / \mathrm{ml}) ; \mathrm{A} 1$, atorvastatin $1 \mu \mathrm{M} ; \mathrm{A} 10$, atorvastatin $10 \mu \mathrm{M}) .{ }^{*} p$-value $<0.05$. Data is presented as mean value \pm S.D., ${ }^{* *} p$-value $<0.01$.

MMP-2 expression was slightly affected by the tested substances. In a dose-dependent manner, atorvastatin decreased metalloproteinase expression, which was amplified by EDPs. Glucose, alone or in combination with s-EDPs, had no influence on MMP-2 gene expression.

The most profound effects were observed on the MMP-1 gene. Glucose alone significantly decreased MMP-1 expression; EDPs alone or in combination with glucose had no effect. Similar to the effects on MMP2, atorvastatin also decreased the expression of MMP-1 in a dose-dependent manner. What is interesting, EDPs augmented the observed effect of atorvastatin on MMP2 gene expression.

In conclusion, atorvastatin had an inhibitory effect on MMP-1, MMP-2, MMP-9 and TIMP-2 expression. The observed effect was related to atorvastatin concentration. High glucose concentration had only a minimal effect on the expression of the genes tested, mainly diminishing MMP-1 expression. EDPs alone had no effect on the expression of the genes tested but amplified the inhibitory effect of atorvastatin on MMP-1 gene expression.

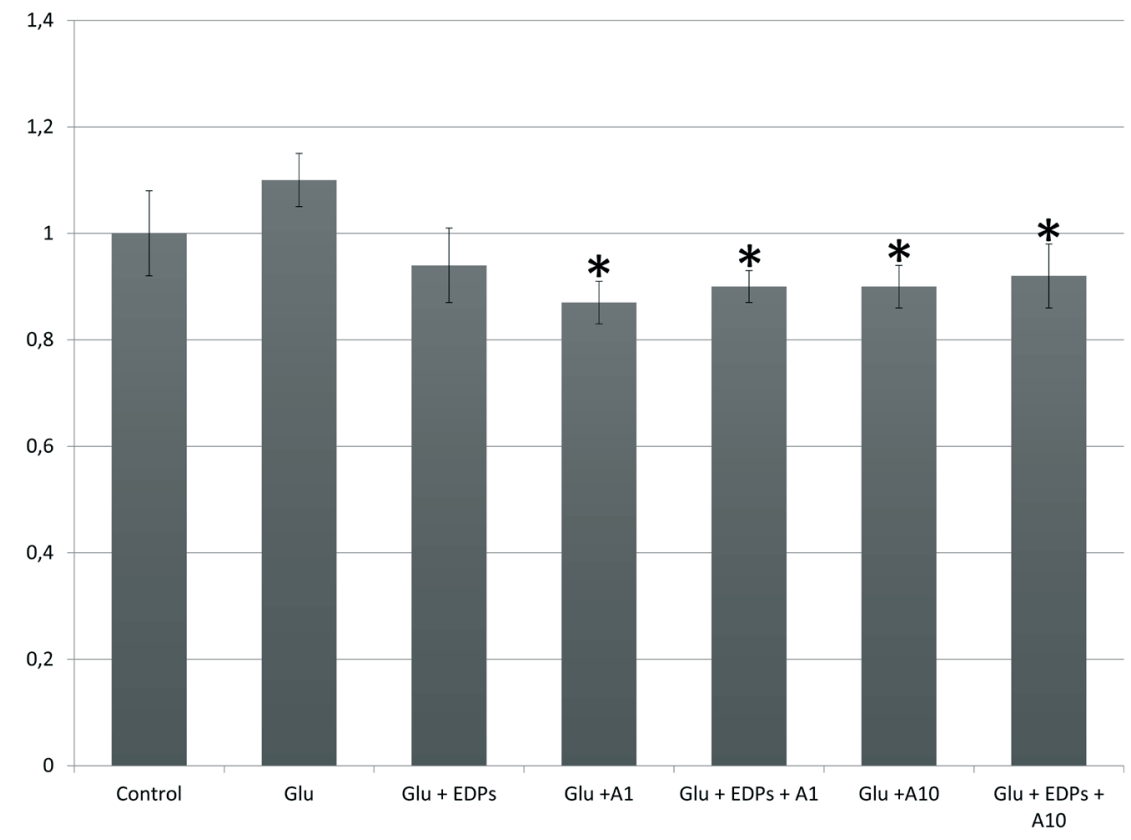

Figure 4. Expression of TIMP-2 gene in HRPE cells.

All results are normalized to a control group, and expressed as percentage of control. Glu, glucose $15 \mathrm{mM}$; EDPs, elastin derived peptides $(0.5 \mu \mathrm{g} / \mathrm{ml}) ; \mathrm{A} 1$, atorvastatin $1 \mu \mathrm{M} ; \mathrm{A} 10$, atorvastatin $10 \mu \mathrm{M}) .{ }^{*} p$-value $<0.05$. Data is presented as mean value $\pm S . D .,{ }^{*} p$-value $<0.01$. 


\section{DISCUSSION}

Changes in MMPs and TIMPs expression induced by hyperglycemia were observed in cultured RPE cells (Lee et al., 2004) and in vascular endothelial cells (Uemura et al., 2001).

Up-regulation of MMP-9 expression was indicated as a factor contributing to the formation of choroidal neovascularization in mice (Lambert et al., 2002).

In our study, the expression of MMP-2 in control HRPE was several thousand times higher than MMP9, thus making MMP-2 the major metalloproteinase expressed under normal conditions. Our results are in agreement with the studies of other authors (Zhuge \& Xu, 2001; Marin-Castano et al., 2005). RPE synthesizes collagens type I-IV and fibronectin. MMP-2 degrades collagen I, IV and laminin - the most important components of Bruch's membrane (Zhuge \& Xu, 2001). This type of metalloproteinases seems to play an important role in the pathogenesis of retinal disorders.

The data concerning MMP expression in retinal pigment epithelial cells is inconsistent, probably due to the differences in study models, the cells used and the duration of experiments. In animal studies, glucose increases retinal MMP-2 and MMP-9 gene expression in streptozotocin-induced diabetes in rats (Giebel et al., 2005). We were unable to confirm these findings as well as the findings of Lee et al. (2004) who observed that hyperglycemia after stimulation of HRPE with glucose, increased the expression of MMP-2 and MMP-9. In our experiment, $15 \mathrm{mM}$ glucose did not change the expression of MMP-2 or -9 during incubation. In the animal model and the in vitro HRPE model, other factors, such as the formation of advanced glycation endproducts (AGE) are likely to play an important role. In our study, we only incubated cells for 24 hours, which is too short to create a significant concentration of AGE in vitro. Thus we could evaluate the influence of sole hyperglycemia and exclude a component of AGE. Giebel and coworkers (2005) did not present MMPs mRNA expression in animals before the 12th week of study, probably because the results were not significantly different or they were simply not evaluated. In the study by Lee et al. (2004), an increase in the expression of MMPs was observed after 14 days of incubation. Therefore we cannot exclude that in order to observe any significant changes in MMPs gene expression, the cells must be incubated with glucose for longer periods of time. The oxidative stress associated with hyperglycemia may also be due to increased concentrations of AGEs (Sulochana et al., 2001). AGEs interact with specific receptors and induce oxidative stress, enhance the expression of vascular cell adhesion molecule 1 (VCAM-1) and increase endothelial adhesiveness to monocytes (Schmidt et al., 1995). Hoffman et al. (2002) reported that AGEs stimulate MMP-2 expression in choroidal endothelial cells (CECs). Hoffmann and coworkers (2006) found that TNF-alfa and VEGF stimulate the secretion of MMP-2 and MMP-9 in RPE cells. Combining both studies, it seems that over-expression of MMP-2 and -9 can take place in pathological conditions, such as diabetes, and in processes related to neovascularization. Thus, factors diminishing MMP-2 and -9 expression may possibly have a beneficial role. In the presented study, atorvastatin decreased the expression of the two metalloproteinases in a dose-dependent manner. It also decreased the expression of TIMP-2 and MMP-1.

In the study performed by Alge-Priglinger et al. (2009), oxidative stress induced MMP-1 expression. Thus, atorvastatin action which leads to the inhibition of MMP-1 mRNA expression should have a beneficial effect. Surprisingly, glucose at a concentration of $15 \mathrm{mM}$ significantly decreased MMP-1 mRNA expression. We were unable to find any studies related to the influence of glucose on MMP-1 expression in RPE cells. However, the effect of glucose on MMP-1 expression in other cells is divergent. Kim and coworkers (2008) found that whereas in human peritoneal mesothelial cells glucose decreases MMP-1 expression, in endothelial cells, it has the opposite effect. Endothelial cells incubated with high glucose concentration over-express the MMP-1 gene (Death et al., 2003).

In our experiment, we did not observe any direct influence of the tested components on the expression of the TIMPs gene in any of the examined groups, with the exception of atorvastatin with glucose and with glucose + EDPs, which statistically significantly decreased TIMP-2 gene expression. These results enable us to conclude that TIMPs expression seems not to be regulated by hyperglycemia or EDPs. Therefore hyperglycemia and EDPs are not involved in the process of regulation of MMPs activation.

The addition in our study of atorvastatin significantly decreased all the examined MMPs expression, but atorvastatin alone influenced TIMP-2 expression. The observed effect was concentration-dependent. Although some authors confirmed the positive effect of statins on MMPs activity, we found no data on the effects of statins on RPE cells. Luan and coworkers (2003) noticed that statins inhibit the secretion of several MMP$1,-2,-3$ and -9 from the vascular smooth muscle and macrophages in humans and rabbits. In the rat model of heart failure, Ichihara and coworkers (2006) reported that pravastatin suppressed an increase in myocardial MMP-2 and -9 activity. The influence of atorvastatin on MMPs expression in our study reflects in vivo results obtained in different vascular localizations. Kajimoto et al. (2009) observed that atorvastatin therapy reduces MMP2 and MMP-9 expression in human abdominal aortic aneurysmal wall. Collin and coworkers (2006) observed the same effect of atorvastatin on MMP-2 expression reduction in coronary arteries of rabbits treated with atorvastatin. Atorvastatin-reduced MMPs gene expression can deeply affect extracellular matrix turnover, which may play an important role in the progression of ocular diseases, including diabetic retinopathy.

\section{REFERENCES}

Ahir A, Guo L, Hussain AA, Marshall J (2002) Expression of metalloproteinases from human retinal pigment epithelial cells and their effects on the hydraulic conductivity of Bruch's membrane. Invest Ophthalmol Vis Sci 43: 458-465.

Alge-Priglinger CS, Kreutzer T, Obholzer K, Wolf A, Mempel M, Kernt M, Kampik A et al. (2009) Oxidative stress-mediated induction of MMP-1 and MMP-3 in human RPE cells. Invest Ophthalmol Vis Sci 50: 5495-5503.

Al-Shabrawey M, Bartoli M, El-Remessy AB, Ma G, Matragoon S, Lemtalsi T, Caldwell RW et al. (2008) Role of NADPH oxidase and Stat 3 in statin-mediated protection against diabetic retinopathy. Invest Ophthalmol Vis Sci 49: 3231-3238.

Brassart B, Fuchs P, Huet E, Alix AJ, Wallach J, Tamburro AM, Delacoux F et al. (2001) Conformational dependence of collagenase (matrix metalloproteinase-1) up-regulation by elastin peptides in cultured fibroblasts. I Biol Chem 276: 5222-5227.

Brew K, Dinakarpandian D, Nagase H (2000) Tissue inhibitors of metalloproteinases: evolution, structure and function. Biochim Biophys Acta 1477: 267-283.

Chan CM, Huang JH, Chiang HS, Wu WB, Lin HH, Hong JY, Hung CF (2010) Effects of (-)-epigallocatechin gallate on RPE cell migration and adhesion. Mol Vis 16: 586-595.

Chong NH, Alexander RA, Gin T, Bird AC, Luthert PJ (2000) TIMP3 , collagen, and elastin immunohistochemistry and histopathology of Sorsby's fundus dystrophy. Invest Ophthalmol Vis Sci 41: 898-902.

Collin B, Busseuil D, Korandji C, Zeller M, Cottin Y, Duvillard L, Rioufol G et al. (2006) Short-term atorvastatin treatment does not modify neointimal morphology but reduces MMP-2 expression in 
normocholesterolemic rabbit stented arteries. I Cardiovasc Pharmacol 47: 428-436.

Collins R, Armitage J, Parish S, Sleight P, Peto R (2004) Heart Protection Study Collaborative Group. Effects of cholesterol-lowering with simvastatin on stroke and other major vascular events in 20536 people with cerebrovascular disease or other high-risk conditions. Lancet 363: 757-767.

Cui JZ, Chiu A, Maberley D, Ma P, Samad A, Matsubara JA (2007) Stage specificity of novel growth factor expression during development of proliferative vitreoretinopathy. Eye (Lond) 21: 200-208.

Cusick M, Chew EY, Chan CC, Kruth HS, Murphy RP, Ferris FL (2003) Histopathology and regression of retinal hard exudates in diabetic retinopathy after reduction of elevated serum lipid levels. Ophthalmology 110: 2126-2133.

Death AK, Fisher EJ, McGrath KC, Yue DK (2003) High glucose alters matrix metalloproteinase expression in two key vascular cells: potential impact on atherosclerosis in diabetes. Atherosclerosis 168: 263-269.

Decanini A, Karunadharma PR, Nordgaard CL, Feng X, Olsen TW, Ferrington DA (2008) Human retinal pigment epithelium proteome changes in early diabetes. Diabetologia 51: 1051-1061.

Dunaief JL, Dentchev T, Ying GS, Milam AH (2002) The role of apoptosis in age-related macular degeneration. Arch Ophthalmol 120: 1435-1442.

Eichler W, Friedrichs U, Thies A, Tratz C, Wiedemann P (2002) Modulation of matrix metalloproteinase and timp-1 expression by cytokines in human RPE cells. Invest Ophthalmol Vis Sci 43: 2767-2773.

Evans JR (2001) Risk factors for age-related macular degeneration. Prog Retin Eye Res 20: 227-253.

Giebel SJ, Menicucci G, McGuire PG, Das A (2005) Matrix metalloproteinases in early diabetic retinopathy and their role in alteration of the blood-retinal barrier. Lab Invest 85: 597-607.

Gupta A, Gupta V, Thapar S, Bhansali A (2004) Lipid-lowering drug atorvastatin as an adjunct in the management of diabetic macular edema. Am J Ophthalmol 137: 675-682.

Hance KA, Tataria M, Ziporin SJ, Lee JK, Thompson RW (2002) Monocyte chemotactic activity in human abdominal aortic aneurysms: role of elastin degradation peptides and the $67-\mathrm{kD}$ cell surface elastin receptor. I V asc Surg 35: 254-261.

Hoffmann S, Friedrichs U, Eichler W, Rosenthal A, Wiedemann P (2002) Advanced glycation end products induce choroidal endothelial cell proliferation, matrix metalloproteinase-2 and VEGF upregulation in vitro. Graefe's Arch Clin Exp Ophthalmol 240: 996-1002.

Hoffmann S, He S, Ehren M, Ryan SJ, Wiedemann P, Hinton DR (2006) MMP-2 and MMP-9 secretion by RPE is stimulated by angiogenic molecules found in choroidal neovascular membranes. Retina 26: 454-461.

Hollborn M, Stathopoulos C, Steffen A, Wiedemann P, Kohen L, Bringmann A (2007) Positive feedback regulation between MMP-9 and VEGF in human RPE cells. Invest Ophthalmol Vis Sci 48: 43604367.

Ichihara S, Noda A, Nagata K, Obata K, Xu J, Ichihara G, Oikawa S et al. (2006) Pravastatin increases survival and suppresses an increase in myocardial matrix metalloproteinase activity in a rat model of heart failure. Cardiovasc Res 69: 726-735.

Johnson PT, Lewis GP, Talaga KC, Brown MN, Kappel PJ, Fisher SK, Anderson DH et al. (2003) Drusen-associated degeneration in the retina. Invest Ophthalmol Vis Sci 44: 4481-4488.

Jones CB, Sane DC, Herrington DM (2003) Matrix metalloproteinases: a review of their structure and role in acute coronary syndrome. Cardiovasc Res 59: 812-823.

Kajimoto K, Miyauchi K, Kasai T, Shimada K, Kojima Y, Shimada A, Niinami H et al. (2009) Short-term 20-mg atorvastatin therapy reduces key inflammatory factors including c-Jun $\mathrm{N}$-terminal kinase and dendritic cells and matrix metalloproteinase expression in human abdominal aortic aneurysmal wall. Atherosclerosis 206: 505-511.

Kim JJ, Li JJ, Kim KS, Kwak SJ, Jung DS, Ryu DR, Yoo TH et al. (2008) High glucose decreases collagenase expression and increases TIMP expression in cultured human peritoneal mesothelial cells. Nephrol Dial Transplant 23: 534-541.

Lambert V, Munaut C, Jost M, Noël A, Werb Z, Foidart JM, Rakic JM (2002) Matrix metalloproteinase-9 contributes to choroidal neovascularization. Am J Pathol 161: 1247-1253.

Lapis K, Tímár J (2002) Role of elastin-matrix interactions in tumor progression. Semin Cancer Biol 12: 209-217.

Lee D, Kim JS, Cho HK, Lee JH (2004) The effects of glucose on the expression of MMP and TIMP in cultured retinal pigment epithelial cells. Korean J Ophthalmol 18: 132.

Luan Z, Chase AJ, Newby AC (2003) Statins inhibit secretion of metalloproteinases-1, $-2,-3$, and -9 from vascular smooth muscle cells and macrophages. Arterioscler Thromb Vasc Biol 23: 769-775.

Ludwig S, Shen GX (2006) Statins for diabetic cardiovascular complications. Curr Vasc Pharmacol 4: 245-251.

Marin-Castaño ME, Csaky KG, Cousins SW (2005) Nonlethal oxidant injury to human retinal pigment epithelium cells causes cell mem- brane blebbing but decreased MMP-2 activity. Invest Ophthalmol Vis Sci 46: 3331-3340.

Nagineni CN, Detrick B, Hooks JJ (1994) Synergistic effects of gamma interferon on inflammatory mediators that induce interleukin- 6 gene expression and secretion by human retinal pigment epithelial cells. Clin Diagn Laboratory Immunol 1: 569-577.

Nagineni CN, Detrick B, Hooks JJ (2000) Toxoplasma gondii infection induces gene expression and secretion of interleukin 1 (IL-1), IL-6, granulocyte-macrophage colony stimulating factor, and intracellular adhesion molecule 1 by human retinal pigment epithelial cells. Infect Immun 68: 407-410.

Noda K, Ishida S, Inoue M, Obata K, Oguchi Y, Okada Y, Ikeda E (2003) Production and activation of matrix metalloproteinase-2 in proliferative diabetic retinopathy. Invest Ophthalmol Vis Sci 44: 21632170.

Ntayi C, Labrousse AL, Debret R, Birembaut P, Bellon G, Antonicelli F, Hornebeck W et al. (2004) Elastin-derived peptides upregulate matrix metalloproteinase-2-mediated melanoma cell invasion through elastin-binding protein. I Invest Dermatol 122: 256-265.

Padgett LC, Lui GM, Werb Z, LaVail MM (1997) Matrix metalloproteinase- 2 and tissue inhibitor of metalloproteinase- 1 in the retinal pigment epithelium and interphotoreceptor matrix: vectorial secretion and regulation. Exp Eye Res 64: 927-938.

Pepper MS (2001) Role of the matrix metalloproteinase and plasminogen activator-plasmin systems in angiogenesis. Arterioscler Thromb Vasc Biol 21: 1104-1117.

Petersen E, Wågberg F, Ängquist KA (2002) Serum concentrations of elastin-derived peptides in patients with specific manifestations of atherosclerotic Disease. Eur I V asc Endovasc Surg 24: 440-444.

Robinet A, Fahem A, Cauchard JH, Huet E, Vincent L, Lorimier S, Antonicelli F et al. (2005) Elastin-derived peptides enhance angiogenesis by promoting endothelial cell migration and tubulogenesis through upregulation of MT1-MMP. J Cell Sci 118: 343-356.

Schmidt AM, Hori O, Chen JX, Li JF, Crandall J, Zhang J, Cao R et al. (1995) Advanced glycation endproducts interacting with their endothelial receptor induce expression of vascular cell adhesion molecule-1 (VCAM-1) in cultured human endothelial cells and in mice. A potential mechanism for the accelerated vasculopathy of diabetes. J Clin Invest 96: 1395-1403.

Sen K, Misra A, Kumar A, Pandey RM (2002) Simvastatin retards progression of retinopathy in diabetic patients with hypercholesterolemia. Diabetes Res Clin Pract 56: 1-11.

Sheridan CM, Occleston NL, Hiscott P, Kon CH, Khaw PT, Grierson I (2001) Matrix metalloproteinases: a role in the contraction of vitreo-retinal scar tissue. Am J Pathol 159: 1555-1566.

Sivaprasad S, Chong NV, Bailey TA (2005) Serum elastin-derived peptides in age-related macular degeneration. Invest Ophthalmol Vis Sci 46: 3046-3051.

Spraul CW, Kaven C, Lang GK, Lang GE (2004) Effect of growth factors on bovine retinal pigment epithelial cell migration and proliferation. Ophthalmic Res 36: 166-171.

Strauss O (2005) The retinal pigment epithelium in visual function. Physiol Rev 85: 845-881.

Sulochana KN, Ramakrishnan S, Rajesh M, Coral K, Badrinath SS (2001) Diabetic retinopathy: Molecular mechanisms, present regime of treatment and future perspectives. Current Science 80: 133-142.

Troger J, Sellemond S, Kieselbach G, Kralinger M, Schmid E, Teuchner B, Nguyen QA et al. (2003) Inhibitory effect of certain neuropeptides on the proliferation of human retinal pigment epithelial cells. Br J Ophthalmol 87: 1403-1408.

Uemura S, Matsushita H, Li W, Glassford AJ, Asagami T, Lee KH, Harrison DG et al. (2001) Diabetes mellitus enhances vascular matrix metalloproteinase activity: role of oxidative stress. Circ Res 88: 1291-1298.

Villarroel M, García-Ramírez M, Corraliza L, Hernández C, Simó R (2009) Effects of high glucose concentration on the barrier function and the expression of tight junction proteins in human retinal pigment epithelial cells. Exp Eye Res 89: 913-920.

Visse R, Nagase H (2003) Matrix metalloproteinases and tissue inhibitors of metalloproteinases: structure, function, and biochemistry. Circ Res 92: 827-839.

Webster L, Chignell AH, Limb GA (1999) Predominance of MMP-1 and MMP-2 in epiretinal and subretinal membranes of proliferative vitreoretinopathy. Exp Eye Res 68: 91-98.

Yamagishi S, Nakamura K, Matsui T, Sato T, Takeuchi M (2006) Potential utility of statins, 3-hydroxy-3-methylglutaryl coenzyme A reductase inhibitors in diabetic retinopathy. Med Hypotheses 66: 10191021.

Yoshida A, Elner SG, Bian ZM, Kunkel SL, Lukacs NW, Elner VM (2001) Thrombin regulates chemokine induction during human retinal pigment epithelial cell/monocyte interaction. Am J Pathol 159: 1171-1180.

Zhuge Y, Xu J (2001) Rac1 mediates type I collagen-dependent MMP2 activation. Role in cell invasion across collagen barrier. J Biol Chem 276: 16248-16256. 